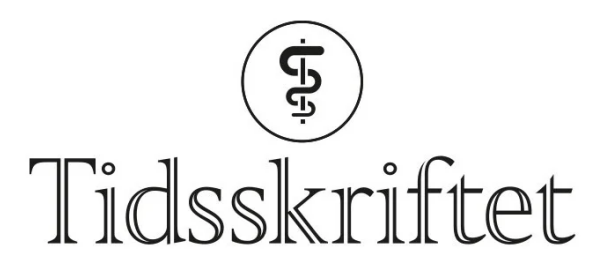

DEN NORSKE LEGEFORENING

\title{
SARS-CoV-2-viruset svekker immunresponsen
}

FRA ANDRE TIDSSKRIFTER

HAAKON B. BENESTAD

Universitetet i Oslo

SARS-CoV-2 hemmer immuncellenes produksjon av antivirale interferoner ved å dempe både produksjon og sekresjon av proteiner.

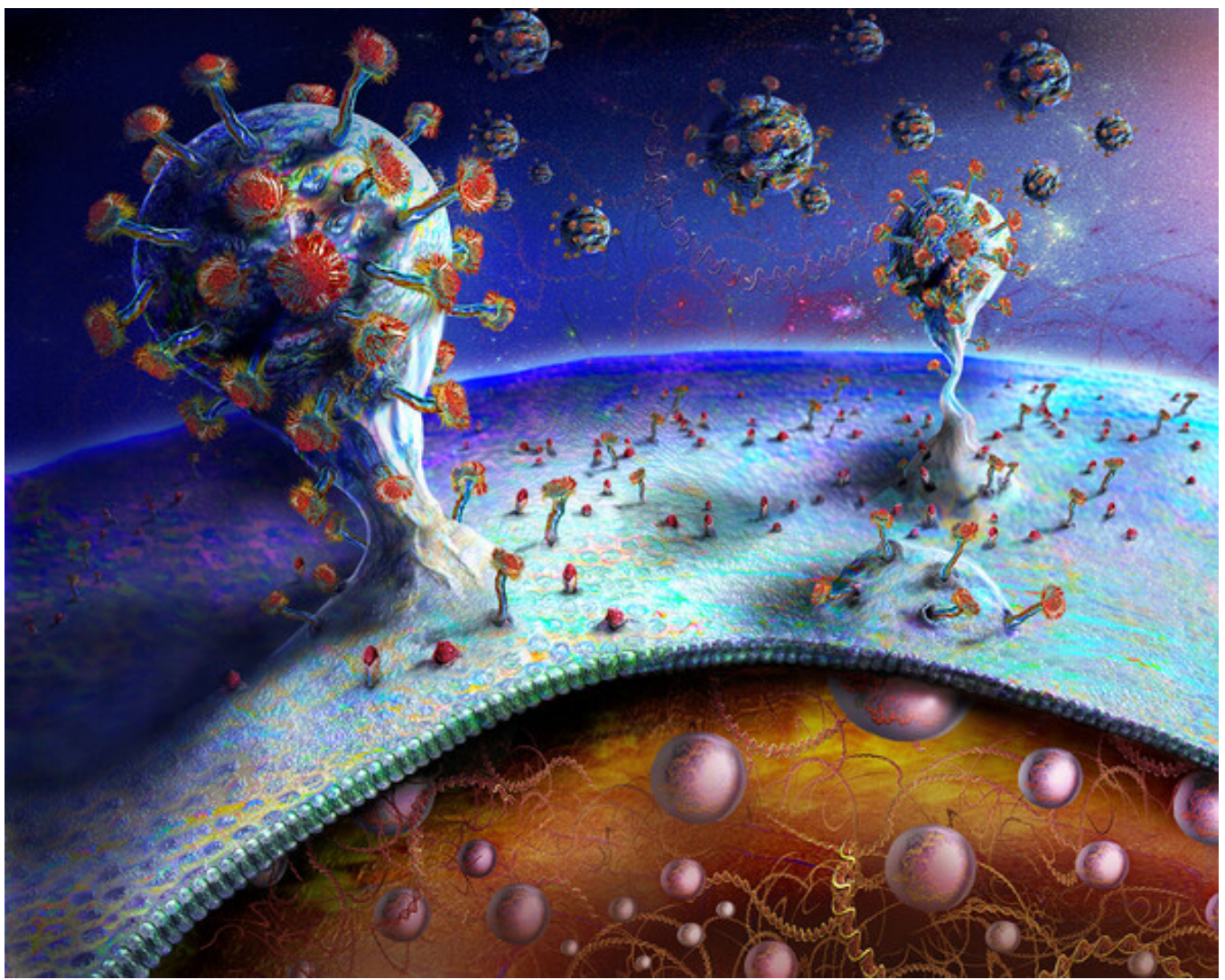

Koronavirus spirende fra en infisert celle. Illustrasjon: Science photo library / NTB Patogenesen ved covid-19-infeksjon er ikke kartlagt. Virus trenger vertscellenes maskineri for å formere seg og for å bli utskilt. Virusets enkeltkjedete RNA-genom koder for 27 proteiner, som har mange ulike funksjoner. Fire proteiner, bl.a. S-proteinet, som er 
essensielt for opptak i celler med ACE2-reseptoren, står for innpakkingen av genomet. Virusgenomet koder også for proteiner som er viktige for virusformeringen, men som dessuten har andre, ukjente funksjoner.

Vårt medfødte immunforsvar kan detektere og blokkere alle trinnene i virusmultiplikasjonen. Celler har sensorer for virus-RNA, som kan signalisere produksjon av bl.a. interferon- $\alpha$ og interferon- $\beta$. Disse kan aktivere hundrevis av antivirale gener. Men virus har også forsvarsmekanismer som kan bryte antivirale mekanismer.

For SARS-CoV-2 er det nylig påvist at fire virusproteiner på ulike måter kan hemme interferondannelsen (1). Ett protein hemmer spleising av ekson-RNA (pre-mRNA) til funksjonelt budbringer-RNA (mRNA). Et annet blokkerer kanalen inn til ribosomet, slik at mRNA ikke kan kode produksjon av cellens eget protein, mens virus-mRNA fortsatt blir translatert. To andre proteiner blokkerer trafikken av virusprotein ut av cellen. Til sammen fører de tre mekanismene til en robust suppresjon av vertens virusforsvar. Kan denne studien ha terapeutiske konsekvenser?

- Man skulle umiddelbart tenke seg at en behandling som styrker vertens eget antivirale forsvar, ville være gunstig, sier Pål Aukrust, som leder den norske delen av Verdens helseorganisasjons Solidarity-studie og Seksjon for klinisk immunologi og infeksjonsmedisin ved Oslo universitetssykehus Rikshospitalet.

- Men Solidarity-studien viste ingen signifikant effekt av interferon- $\beta$ sammenlignet med standardbehandling, hverken på mortalitet, andel pasienter som krevde respiratorbehandling, eller lengde på sykehusopphold, sier han.

Dette viser hvor utfordrende det er å påvirke kompliserte immunologiske prosesser under alvorlige infeksjoner. Selv om interferoner har viktige antivirale effekter, har de også potensielt skadelige proinflammatoriske effekter. Både for lite av en gunstig mediator og for mye, som ved en cytokinstorm, er uheldig. Antiviral behandling kan være viktig i en tidlig fase av covid-19-infeksjon, mens andre former for behandling, slik som immunmodulerende behandling med deksametason, velges ved alvorlig og kritisk covid19-infeksjon, sier Aukrust.

\section{LITTERATUR}

1. Banerjee AK, Blanco MR, Bruce EA et al. SARS-CoV-2 disrupts splicing, translation, and protein trafficking to suppress host defenses. Cell 2020; 183: Soog2-8674(20)31310-6. [PubMed][CrossRef]

Publisert: 14. desember 2020. Tidsskr Nor Legeforen. DOI: 10.4045/tidsskr.20.0909

(C) Tidsskrift for Den norske legeforening 2023. Lastet ned fra tidsskriftet.no 26. april 2023. 